\title{
GIBBERELLIN AND CYTOKININ EFFECTS ON SOYBEAN GROWTH
}

\author{
Vagner Maximino Leite ${ }^{1 *}$; Ciro Antonio Rosolem ${ }^{1}$; João Domingos Rodrigues ${ }^{2}$ \\ ${ }^{1}$ UNESP/FCA - Depto. de Produção Vegetal/Setor de Agricultura, C.P. 237 - 18603-970 - Botucatu, SP - Brasil. \\ ${ }^{2}$ UNESP/IB - Depto. de Botânica, C.P. 510 - 18618-000 - Botucatu, SP - Brasil. \\ *Corresponding author <vagren@ig.com.br>
}

\begin{abstract}
Soybean is an important crop in Brazil. Nonetheless, there are no reports on the use of plant growth regulator potential in relation to this crop in the national literature. To better understand the role of these compounds, a pot experiment was carried out to study effects of $\mathrm{GA}_{3}$ and cytokinin on the vegetative growth of the soybean. $\mathrm{GA}_{3}\left(50 \mathrm{mg} \mathrm{L}^{-1}\right)$ was applied as seed treatment, leaving plants with water application as control. $\mathrm{GA}_{3}\left(100 \mathrm{mg} \mathrm{L}^{-1}\right)$ and cytokinin $\left(30 \mathrm{mg} \mathrm{L}^{-1}\right)$ were sprayed on leaves at the physiological stage V3/ $\mathrm{V} 4$, and 15 days after, cytokinin $\left(30 \mathrm{mg} \mathrm{L}^{-1}\right)$, also as foliar spray. Seed treatment decreased plant emergence and initial soybean root growth, but as the season progressed, differences in root growth disappeared; plants were shorter, and presented a decrease in the number of nodes, in stem diameter, in leaf area and in dry matter yield. Conversely, foliar application of $\mathrm{GA}_{3}$ led to an increase in plant height, first node height and stem diameter. Leaf area and dry matter production also increased as a result of GA foliar application. There was no effect of exogenous gibberellin and cytokinin on the number of soybean leaves, number of stem branches and root dry matter. Joint application of gibberellin and cytokinin tended to inhibit gibberellin effects. Cytokinin applied to leaves during soybean vegetative growth was not effective in modifying any of the evaluated plant growth variables.
\end{abstract}

Key words: Glycine max, gibberellic acid, gibberellin, aminopurin, plant growth regulator

\section{GIBERELINA E CITOCININA NO CRESCIMENTO DA SOJA}

\begin{abstract}
RESUMO: A soja é uma das principais culturas no Brasil, porém não há relatos do potencial de utilização dos fitorreguladores nessa cultura na literatura nacional. Para saber mais sobre estes compostos, um experimento em vasos foi conduzido para estudar o efeito do $\mathrm{GA}_{3}$ e citocinina (CK) sobre o crescimento vegetativo e floração da soja. $\mathrm{GA}_{3}\left(50 \mathrm{mg} \mathrm{L}^{-1}\right)$ foi aplicado como tratamento de sementes. Plantas somente com aplicação de água foram aplicadas como controle. Foram feitas duas aplicações foliares, sendo na primeira aplicado $100 \mathrm{mg} \mathrm{L}^{-1}$ de $\mathrm{GA}_{3}$, associado ou não a $30 \mathrm{mg} \mathrm{L}^{-1} \mathrm{de} \mathrm{CK}$, e na segunda $30 \mathrm{mg} \mathrm{L}^{-1} \mathrm{de} \mathrm{CK}$. $\mathrm{O}$ tratamento de sementes diminuiu a emergência de plântulas e o comprimento de raiz, porém, com o decorrer do experimento, a diferença no crescimento radicular desapareceu. Além destes efeitos, as plantas foram menores e apresentaram uma diminuição no número de nós, diâmetro de caule, área foliar e produção de matéria seca. A aplicação foliar de $\mathrm{GA}_{3}$ aumentou a altura da planta, altura do primeiro nó e diâmetro de caule. A área foliar e a produção de matéria seca também aumentaram com a aplicação foliar de GA. Não foi verificado efeito de $\mathrm{GA}_{3}$ e $\mathrm{CK}$ exógenas sobre o número de folhas, número de ramificações e matéria seca da raiz. A aplicação conjunta de giberelina e citocinina tendeu a diminuir os efeitos da giberelina. Citocinina aplicada às folhas durante o crescimento vegetativo da soja, não apresentou efeito sobre quaisquer variáveis analisadas.
\end{abstract}

Palavras-chave: Glycine max, GA, ácido giberélico, aminopurina, fitorreguladores

\section{INTRODUCTION}

Plant regulators are organic compounds which, in small amounts, somehow modify a given physiological plant process and rarely act alone, as the action of two or more of these compounds is necessary to produce a physiological effect. Gibberellins (GAs) play an essential role in many aspects of plant growth and development, such as seed germination (Haba et al., 1985, Khafagi et al., 1986, Kumar \& Neelakandan, 1992; Maske et al., 1997), stem elongation and flower development (Yamaguchi \& Kamiya, 2000).

They are extensively used to manipulate flower formation and fruit set in horticultural plants. When applied at the pre-blooming stage, GAs decrease the number of flowers and fruit set, probably by increasing vegetative mass which, in turn, shares the photoassimilates with the fruit (Birnberg \& Brenner, 1987). This hypothesis is also sustained by King et al. (2000), who reported greater stem growth in Fuschia hibrida and Pharbitis nil, resulting in the inhibition of flowering. 
Cytokinins (CK) are known to stimulate or inhibit a great number of physiological processes. For soybean, however, great variability can be observed in reported results. These dissimilar results primarily occur because of differences between concentrations utilized and differences in the physiological stages at which these products are applied. CK can be utilized in a variety of applications, from the treatment of seeds (Riedell et al., 1985) to applications during flowering (Dyer et al., 1986), and the same is true about GA (Khafagi et al., 1986; Urwiler et al., 1988; Maske et al., 1997).

Since the international literature on the subject presents many conflicting results, and no papers could be found on the utilization of GA and CK for soybean in Brazil, where the potential of these plant regulators is seldom used in annual crops, the objective of this work was to study the effect of products containing GA and CK applied at different physiological stages during soybean growth.

\section{MATERIAL AND METHODS}

The experiment was carried out in a greenhouse using the soybean cultivar IAC 17, in 12-L capacity pots filled with a Typic Acrortox, sifted through a $4 \mathrm{~mm}$ mesh sieve. Results of soil chemical analysis, according to Raij \& Quaggio (1983), are: $4.4 \mathrm{pH}$ in $\mathrm{CaCl}_{2}, 13 \mathrm{mg} \mathrm{dm}^{-3} \mathrm{P}$ in resin, $55 \mathrm{mmol}_{\mathrm{c}} \mathrm{dm}^{-3} \mathrm{H}+\mathrm{Al}, 2.5 \mathrm{mmol}_{\mathrm{cm}} \mathrm{dm}^{-3} \mathrm{~K}^{+}$, $24 \mathrm{mmol} \mathrm{dm}^{-3} \mathrm{Ca}^{+2}, 14 \mathrm{mmol} \mathrm{dm}_{\mathrm{c}} \mathrm{Mg}^{+2}$, and $42 \%$ base saturation. Acidity corrections were performed with dolomitic lime, increasing the base saturation to $70 \%$, and fertility corrections consisted of single superphosphate at a rate sufficient to reach $150 \mathrm{mg} \mathrm{dm}^{-3} \mathrm{P}$ and potassium chloride to reach $3.5 \mathrm{mmol}_{\mathrm{c}} \mathrm{dm}^{-3} \mathrm{~K}^{+}$. Based on the fertility history of the area from where soil was collected, $1 \mathrm{mg} \mathrm{dm}^{-3}$ zinc as sulfate, and $0.5 \mathrm{mg} \mathrm{dm}^{-3}$ boron as boric acid, were added.

Treatments consisted of a $50 \mathrm{mg} \mathrm{L}^{-1} \mathrm{GA}_{3}$ solution, as utilized by Kumar \& Neelakandan (1992) and Maske et al. (1997), as seed treatment, and as foliar applications (two) with solutions containing $100 \mathrm{mg} \mathrm{L}^{-1} \mathrm{GA}_{3}$ and $30 \mathrm{mg} \mathrm{L}^{-1} \mathrm{CK}$ as PB2 N-(Phenylmethyl)-9tetrahydropyranyl-6-aminopurine, combined or not.

After immersion for eight hours in $\mathrm{GA}_{3}$ solution or distilled water, both under forced aeration so as to maintain the respiration process, seeds were inoculated with Bradirhyzobium japonicum in peat (10 $\mathrm{g} \mathrm{kg}^{-1}$ seeds) and 15 seeds were placed in each pot at a mean depth of $1 \mathrm{~cm}$. After sowing, the soil in the pots was covered with a 2-cm deep layer of thick sand to help emergence, avoid the formation of a crust and alleviate variations in temperature. The number of emerged plants was evaluated 15 days after sowing, followed by thinning, leaving two uniform and representative plants per pot.
Foliar applications were performed when the plants had between three and four completely unfolded trifoliolate leaves, and fifteen days later, when plants had between five and six completely unfolded trifoliolate leaves. A low volume sprayer connected to a pressure regulator was utilized, delivering constant pressure and volume, and $1 \mathrm{~mL}$ of the solution was applied per plant. Control plants were sprayed with distilled water.

Evaluations were performed at three different periods: immediately before the first foliar application; immediately before the second foliar application; and 30 days after the second evoluation, when plants were at physiological stage R3 (legume with $0.5 \mathrm{~cm}$ in length at any of the upper four nodes having a completely unfolded leaf). The following variables were analyzed at each sampling: plant height, height of first node, root collar diameter, leaf area (area of all leaflets, measured with a leaf area integrator), dry matter mass, root length determined by the Tennant's (1975) method, number of leaves, number of branches, number of nodes and length of branches.

To obtain root dry matter mass, the root was divided into two still fresh portions, that were then weighed. One portion was kept for 3 days in a forced air circulation oven at $60^{\circ} \mathrm{C}$ and then weighed again; the other was placed in plastic containers filled with $50 \%$ alcohol and taken to a refrigerator for length assessment. The total mass was estimated through the ratio obtained between the wet and dry portions.

The experiment consisted of twelve treatments with four replicates, and each plot consisted of a pot containing two plants. The adopted experimental setup was a completely randomized design and statistical differences between treatments were detected by Tukey test $(P=0.05)$.

\section{RESULTS AND DISCUSSION}

Even though an increase in the number of leaves was verified after treatment with $\mathrm{GA}_{3}$ by Castro et al. (1990) for bean plants, and by Harb (1992) for Vicia faba, similar results were not obtained in the present work for soybean (data not shown), as well as for pea by Saimbhi et al. (1975). This demonstrates that comparisons between different species should not be made, because the response could be related either to the different application techniques and rates (King et al., 2000), or to the utilized soybean cultivar (Nalawadi et al., 1973).

An effect of CK on the evaluated variables was expected, but not observed, e.g. number of leaves and branches (not shown) which did not present any effect related to CK. Maybe CK is involved in the development of leaves and branches in plants under adverse conditions, such as low luminosity, as demonstrated by Sharma \& Walia (1996), or high aluminum concentration, as shown by Pan et al. $(1988 ; 1989)$.

Scientia Agricola, v.60, n.3, p.537-541, Jul./Sept. 2003 
The number of plants that emerged 15 days after sowing decreased for the treatment $\mathrm{GA}_{3}$ in seeds (Table 1). The same result was found by Khafagi et al. (1986) while working with seeds imbibed for $6 \mathrm{~h}$ in $\mathrm{GA}_{3}$ solutions, concetrations ranging from 50 to $100 \mathrm{mg} \mathrm{L}^{-1}$. Conversely, Kumar \& Neelakandan (1992) and Maske et al. (1997), using the same concentrations, and Haba et al. (1985) utilizing $0.1 \mathrm{mg} \mathrm{L}^{-1} \mathrm{GA}_{3}$ and imbibition for three hours, obtained an increase in germination.

Since seeds in the control treatment were imbibed for the same time, under the same conditions, the treatment methodology can not be hold responsible for the decrease observed in the number of emerged plants. One of the possible explanations could be the different cultivars utilized by the various authors, as demonstrated by Nalawadi et al. (1973), who utilized 18 different cultivars and observed increase in germination in some and a lack of sensitivity in others, under similar treatment, or even at much higher concentrations, 0.2 to $1 \mathrm{mg} \mathrm{GA}_{3}$ per seed, as utilized by Riedell et al. (1985).

No difference between treatments were observed for plant height in the first evaluation (Table 1). Since GA translocation occurs mainly through the symplast (Castro \& Melotto, 1989), it could be the cause for the difference between responses, because when $\mathrm{GA}_{3}$ is utilized via foliar application, an increase in hypocotyl length and in the length of the two nodes immediately above it can be verified and, consequently, affect the height of plants at that stage (Mislevy et al., 1989).

Exogenous gibberellin applied to seeds may not translocate much to the aerial part of plants, and this perhaps occurs to an extent that is enough to increase hypocotyl size, but is insufficient to affect plant height. As a matter of fact, in agreement with results by Bensen et al. (1990), demonstrate that the hypocotyl growth rate is directly associated with the amount of GA.

Table 1 - Results of plant emerged, plant height, first node height, stem diameter, leaf area, total dry matter and length root of soybean plants cv. IAC 17 under seed treatment with $\mathrm{GA}_{3}$ and leaf application of $\mathrm{GA}_{3}$ and $\mathrm{CK}$.

\begin{tabular}{|c|c|c|c|c|c|c|c|c|c|}
\hline \multicolumn{3}{|c|}{$\begin{array}{l}\text { Treatments } \\
\text { First Evaluation }\end{array}$} & \multirow[t]{2}{*}{$\begin{array}{c}\text { Plant } \\
\text { Emerged }\end{array}$} & \multirow[t]{2}{*}{$\begin{array}{l}\text { Plants } \\
\text { Height }\end{array}$} & F.N.H. ${ }^{1}$ & \multirow{2}{*}{$\begin{array}{c}\begin{array}{c}\text { Diameter } \\
\text { Stem }\end{array} \\
\mathrm{mm}\end{array}$} & \multirow{2}{*}{$\begin{array}{c}\begin{array}{c}\text { Lea } \\
\text { Area }\end{array} \\
\mathrm{cm}^{2}\end{array}$} & \multirow{2}{*}{$\frac{\text { T.D.M. }^{2}}{\mathrm{~g}}$} & \multirow{2}{*}{$\begin{array}{c}\begin{array}{r}\text { Lengtl } \\
\text { Root }\end{array} \\
\mathrm{m}\end{array}$} \\
\hline T.S. & $\begin{array}{c}\text { 1a } \\
\text { application }\end{array}$ & $\begin{array}{c}2 \mathrm{a} \\
\text { application }\end{array}$ & & & - & & & & \\
\hline $\mathrm{No} \mathrm{GA}_{3}$ & & & $8.4 \mathrm{a}^{*}$ & $17.1 \mathrm{a}$ & - & $2.2 \mathrm{a}$ & $237 \mathrm{a}$ & $1.35 \mathrm{a}$ & $184 \mathrm{a}$ \\
\hline With $\mathrm{GA}_{3}$ & & & $5.8 \mathrm{~b}$ & $17.2 \mathrm{a}$ & - & $2.1 \mathrm{a}$ & $237 \mathrm{a}$ & $1.24 \mathrm{a}$ & $94 \mathrm{~b}$ \\
\hline VC \% & & & 8.91 & 12.12 & - & 14.08 & 15.07 & 19.45 & 33.62 \\
\hline \multicolumn{10}{|c|}{ Second Evaluation } \\
\hline & No $\mathrm{GA}_{3}$ & & & $66.5 \mathrm{bc}$ & $5.9 \mathrm{~b}$ & $9.3 \mathrm{a}$ & $1951 \mathrm{a}$ & $14.06 \mathrm{a}$ & 199 a \\
\hline \multirow[t]{3}{*}{$\mathrm{No} \mathrm{GA}_{3}$} & With $\mathrm{GA}_{3}$ & & & $98.5 \mathrm{a}$ & $6.1 \mathrm{~b}$ & $9.1 \mathrm{a}$ & $1984 \mathrm{a}$ & $14.52 \mathrm{a}$ & $255 \mathrm{a}$ \\
\hline & $\mathrm{GA}_{3}+\mathrm{CK}$ & & & $101.4 \mathrm{a}$ & $5.5 \mathrm{~b}$ & $9.5 \mathrm{a}$ & $2183 a$ & $16.41 \mathrm{a}$ & $266 \mathrm{a}$ \\
\hline & $\mathrm{No} \mathrm{GA}_{3}$ & & & $55.0 \mathrm{c}$ & $8.6 \mathrm{~b}$ & $7.2 \mathrm{~b}$ & $1328 \mathrm{a}$ & 8.09 a & $190 \mathrm{a}$ \\
\hline \multirow[t]{2}{*}{ With $\mathrm{GA}_{3}$} & With $\mathrm{GA}_{3}$ & & & $104.0 \mathrm{a}$ & $11.5 \mathrm{a}$ & $8.6 \mathrm{ab}$ & $2166 a$ & $16.22 \mathrm{a}$ & $294 \mathrm{a}$ \\
\hline & $\mathrm{GA}_{3}+\mathrm{CK}$ & & & $86.6 \mathrm{ab}$ & $9.0 \mathrm{ab}$ & $7.6 \mathrm{~b}$ & $1476 \mathrm{a}$ & $10.18 \mathrm{a}$ & 199 a \\
\hline $\mathrm{VC} \%$ & & & & 12.73 & 23.41 & 7.57 & 20.86 & 28.79 & 31.52 \\
\hline \multicolumn{10}{|c|}{ Third Evaluation } \\
\hline & No $\mathrm{GA}_{3}$ & - & & $108.8 \mathrm{cde}$ & $5.1 \mathrm{a}$ & $13.3 \mathrm{a}$ & 4957 a & $40.73 \mathrm{a}$ & $278 \mathrm{a}$ \\
\hline & With $\mathrm{GA}_{3}$ & - & & $139.8 \mathrm{abcd}$ & $6.5 \mathrm{a}$ & $12.8 \mathrm{a}$ & $5070 \mathrm{a}$ & $39.79 \mathrm{a}$ & $289 \mathrm{a}$ \\
\hline \multirow[t]{6}{*}{ No $\mathrm{GA}_{3}$} & $\mathrm{GA}_{3}+\mathrm{CK}$ & - & & $148.3 \mathrm{ab}$ & $5.6 \mathrm{a}$ & $13.6 \mathrm{a}$ & 5010 a & $48.99 \mathrm{a}$ & $382 \mathrm{a}$ \\
\hline & No $\mathrm{GA}_{3}$ & $\mathrm{CK}$ & & $113.3 \mathrm{cde}$ & $5.6 \mathrm{a}$ & $12.8 \mathrm{a}$ & $5141 \mathrm{a}$ & $41.26 \mathrm{a}$ & $307 \mathrm{a}$ \\
\hline & With $\mathrm{GA}_{3}$ & $\mathrm{CK}$ & & $155.0 \mathrm{a}$ & $5.3 \mathrm{a}$ & $14.1 \mathrm{a}$ & $6094 \mathrm{a}$ & $48.90 \mathrm{a}$ & 393 a \\
\hline & $\mathrm{GA}_{3}+\mathrm{CK}$ & $\mathrm{CK}$ & & $152.3 \mathrm{a}$ & $7.4 \mathrm{a}$ & $13.4 \mathrm{a}$ & 5759 a & $46.65 \mathrm{a}$ & $357 \mathrm{a}$ \\
\hline & No $\mathrm{GA}_{3}$ & - & & $90.8 \mathrm{e}$ & $9.1 \mathrm{a}$ & $11.8 \mathrm{a}$ & $4404 \mathrm{a}$ & $37.83 \mathrm{a}$ & $315 a$ \\
\hline & With $\mathrm{GA}_{3}$ & - & & $156.0 \mathrm{a}$ & $10.0 \mathrm{a}$ & $13.4 \mathrm{a}$ & $5326 \mathrm{a}$ & $45.54 \mathrm{a}$ & $295 \mathrm{a}$ \\
\hline \multirow[t]{4}{*}{ With $\mathrm{GA}_{3}$} & $\mathrm{GA}_{3}+\mathrm{CK}$ & - & & $142.5 \mathrm{abc}$ & $8.1 \mathrm{a}$ & $13.1 \mathrm{a}$ & $5122 \mathrm{a}$ & $44.06 \mathrm{a}$ & $302 a$ \\
\hline & $\mathrm{No} \mathrm{GA}_{3}$ & CK & & $104.0 \mathrm{de}$ & $7.4 \mathrm{a}$ & $12.9 \mathrm{a}$ & $5189 \mathrm{a}$ & $39.31 \mathrm{a}$ & $315 \mathrm{a}$ \\
\hline & With $\mathrm{GA}_{3}$ & CK & & $146.0 \mathrm{abc}$ & $8.8 \mathrm{a}$ & $13.5 \mathrm{a}$ & $5858 \mathrm{a}$ & $47.86 \mathrm{a}$ & $416 \mathrm{a}$ \\
\hline & $\mathrm{GA}_{3}+\mathrm{CK}$ & $\mathrm{CK}$ & & $143.3 \mathrm{abc}$ & $8.4 \mathrm{a}$ & $13.0 \mathrm{a}$ & $5240 \mathrm{a}$ & $41.08 \mathrm{a}$ & $313 \mathrm{a}$ \\
\hline $\mathrm{VC} \%$ & & & & 11.52 & 28.27 & 11.30 & 20.47 & 17.40 & 35.25 \\
\hline
\end{tabular}

*Averages followed by the same letter do not differ; Tukey test, $P=0.05$. ${ }^{1}$ First node height. ${ }^{2}$ Total dry matter. 
The foliar application of $\mathrm{GA}_{3}$, in association or not with $\mathrm{CK}$, resulted in larger plants in the two other assessments, no matter if seeds were treated or not. The increase in plant stem growth as a response to $\mathrm{GA}_{3}$ occurs as a consequence of cell elongation (E1 Fouly et al., 1988; Tanimoto, 1990). Valio \& Schwabe (1978) observed negative interaction between GA and CK on stem elongation in bean plants. That can also be observed in the results herein obtained, seeing that both regulators promoted elongation when used separately, but when used together, CK inhibited the full action of $\mathrm{GA}_{3}$.

Because of the extensive list of bibliographic references on the effect of $\mathrm{GA}_{3}$ over hypocotyl elongation, and the consequent increase in first node height (Riedell et al., 1985; Mislevy et al., 1988; Bensen et al., 1990; Kumar \& Neelakandan, 1992; Maske et al., 1997), this characteristic was only analyzed from the second evaluation onward. The first foliar application of $\mathrm{GA}_{3}$ after its application as seed treatment caused an increase in first node height (Table 1), providing evidence of translocation through the symplast, characterized by plant height. The presence of CK together with GA decreases its action, but it does not differ from the isolated application of GA. These tendencies persisted at the third evaluation, but the differences between treatments disappeared, demonstrating that the effects provided by GA are short-lived, since no effect of the foliar application of $\mathrm{GA}_{3}$ was observed for this evaluation.

No difference was detected at the first evaluation with regard to the root collar diameter of plants (Table 1). In the second evaluation, however, the means obtained for the treatment without $\mathrm{GA}_{3}$ as seed treatment were higher than for treated plants, because hypocotyl growth was greater in length than in thickness. This smaller diameter occurs because of a decrease in the size of parenchymatous cells and a reduction in the layers of cells in the vascular cylinder (El Fouly et al., 1988). Differences were not observed in the third evaluation, demonstrating that plants presenting etiolation symptoms from $\mathrm{GA}_{3}$ application had recovered.

Since plants that received foliar applications of $\mathrm{GA}_{3}$ were higher, added to the fact that smaller diameters would be maintained during the entire cycle and could promote lodging, causing expected field losses at harvest time. When plants recover their root collar diameter, however, this possibility becomes less likely.

Greater leaf area means were observed for plants of treatments with foliar $\mathrm{GA}_{3}$, but there was no difference between treatments (Table 1). Since these results were obtained 15 days after application, they are probably compatible with those presented by El Fouly et al. (1988), who found values larger than the control only until 10 days after $\mathrm{GA}_{3}$ application. Since the number of leaves (data not shown) did not present differences with respect to the applied treatments, the increase in leaf area was attributed to cell elongation, as discussed before.
In addition, seed treatment with $\mathrm{GA}_{3}$ caused a delay in plant root growth during the first evaluation. Since root dry matter was not affected as well, it is fair to infer that the roots of treated plants became thicker because they had shorter root lengths and similar amounts of root dry matter (data not shown). The effect of $\mathrm{GA}_{3}$ on root growth is indirect, by means of its effect on the growth of the aerial part, because of the action exerted by $\mathrm{GA}_{3}$ on cell elongation (Tanimoto, 1990). No difference, however, was found in dry matter mass for the aerial part (data not shown) that would justify this smaller growth of the root system, thus eliminating this hypothesis.

Root thickening is a typical symptom of the physiological effect of ethylene. Therefore, the lengthshortening effect of $\mathrm{GA}_{3}$ on roots might have occurred because of an increase in the production of ethylene, caused by an increase in the synthesis of ACC (1Aminocyclopropane-1-carboxilic acid) (Kaneta et al., 1997).

The effect of $\mathrm{GA}_{3}$ on the growth of the aerial part may lead one to believe that, consequently, roots would grow as well, causing in turn an increase in total dry matter Tanimoto (1990). This result can be confirmed by Maske et al. (1997), in seedlings originated from seeds treated with $\mathrm{GA}_{3}$.

The results presented in Table 1, however, as well as those obtained by Saimbhi et al. (1975) and Garcia \& Guardiola (1981), follow a different direction. This difference in results must be attributed to the evaluation which was made at a later time, when the plant was no longer a seedling, and to the short-lived effect of the gibberellins, that might have allowed the treatments to be very similar in behavior so as not to reveal differences.

\section{ACKNOWLEDGEMENTS}

The authors would like to express their gratitute to FAPESP for supporting.

\section{REFERENCES}

BENSEN, R.J.; BEALL, F.D.; MULLET, J.E.; MORGAN, P.W. Detection of endogenous gibberellins and their relationship to hypocotyl elongation in soybean seedlings. Plant Physiology, v.94, p.77-84, 1990.

BIRNBERG, P.R.; BRENNER, M.L. Effect of gibberellic acid on pod set in soybean. Plant Growth Regulation, Dordrecht, v.5, p.195-206, 1987.

CASTRO, P.R.C.; MELOTTO, E. Bioestimulantes e hormônios aplicados via foliar. In: BOARETO, A.E.; ROSOLEM, C.A. (Ed) Adubação foliar. Campinas: Fundação Cargill, 1989. v.1, cap.8, p.191-235.

CASTRO, P.R.C.; APPEZZATO, B.; LARA, C.W.W.R.; PELISSARI, A.; PEREIRA, M.; MEDINA, M.J.A.; BOLONHEZI, A.C.; SILVEIRA, J.A.G. Ação de reguladores vegetais no desenvolvimento, aspectos nutricionais, anatômicos e na produtividade do feijoeiro (Phaseolus vulgaris cv. Carioca). Anais da ESALQ, v.47, p.11-28, 1990.

DYER, D.; CARLSON, D.R.; COTTERMAN, C.D.; SIKORSKI, J.A. The role of cytokinin in soybean pod set regulation. In: PLANT GROWTH REGULATION, St. Petersburg Beach, 1986. Proceedings. St. Petersburg Beach, 1986. p.130. 
EL FOULY, M.M.; SAKR, R.; FOUAD, M.K.; ZAHER, A.M.; FAWZI, A.F.A. Effect of GA, CCC and B-9 on morphophysiological characters and yield of kidney beans (Phaseolus vulgaris L.) Journal of Agronomy Crop Sciences, v.160, p.94-101, 1988.

GARCIA, L.A.; GUARDIOLA, J.L. Effect of gibberellic acid on ion uptake selectivity in pea seedlings. Planta, v.153, p.494-496, 1981.

HABA, P. De-La; ROLDAN, J.M.; JIMENEZ, F. Antagonistic effect of gibberellic acid and boron on protein and carbohydrate metabolism of soybean germinating seeds. Journal of Plant Nutrition, v.8, p.1061$1073,1985$.

HARB, E.Z. Effect of soaking seeds in some growth regulators and micronutrients on growth, some chemical constituents and yield of faba bean and cotton plants. Bulletin of the Faculty Agriculture of University of Cairo, v.43, p.429-452, 1992.

KANETA, T.; KAKIMOTO, K.; SHIBAOKA,H. Gibberellin A3 causes a decrease in the accumulation of mRNA for ACC oxidase and in the activity of the enzyme in azuki bean (Vigna angularis) epicotyls. Plant and Cell Physiology, v.38, p. 1135-1141, 1997.

KHAFAGI, O.A.; KHALAF, S.M.; El-LAWENDY, W.I. Effect of $\mathrm{GA}_{3}$ and CCC on germination and growth of soybean, common bean, cowpea and pigeon pea plants grown under different levels of salinity. Annals of Agricultural Science, v.24, p.1965-1982, 1986.

KING, R.W.; SETO, H.; SACHS, R.M. Response to gibberellin structural variants shows that ability to inhibit flowering correlates with effectiveness for promoting stem elongation of some plant species. Plant Growth Regulation, v.19, p.8-14, 2000.

KUMAR, K.G.A.; NEELAKANDAN, N. Effect of growth regulators on seedling vigour in soybean (Glycine $\max$ (L.) Merr.) Legume Research, v.15, p.181-182, 1992.

MASKE, V.G.; DOTALE, R.D.; SORTE, P.N.; TALE, B.D.; CHORE, C.N. Germination, root and shoot studies in soybean as influenced by GA3 and NAA. Journal of Soils and Crops, v.7, p.147-149, 1997.

MISLEVY, P.; BOOTE, K.J.; MARTIN, F.G. Soybean response to gibberellic acid. I. Time of application relative to emergence. Field Crops Research, v.19, p.113-121, 1988.

MISLEVY, P.; BOOTE, K.J.; MARTIN, F.G. Soybean response to gibberellic acid treatments. Journal Plant Growth Regulation, v.8, p.11-18, 1989.

NALAWADI, U.G.; PRITHVI, R, KRISHNAMURTHY, K. Improvement in the seed germination of soybean varieties by pre-soaking treatments. Indian Journal of Agricultural Sciences, v.43, p.546-550, 1973.
PAN, W.L.; HOPKINS, A.G.; JACKSON, W.A. Aluminun-inhibited shoot development in soybean: a possible consequence of impaired cytokinin supply. Communications in Soil Sciences and Plant Analysis, v.19, p.1143-1153, 1988.

PAN, W.L.; HOPKINS, A.G.; JACKSON, W.A. Aluminun inhibiton of shoot lateral branches of Glycine max and reversal by exogenous cytokinin. Plant and Soil, v.120, p.1-9, 1989.

RAIJ, B. van.; QUAGGIO, J.A. Métodos de análise de solo para fins de fertilidade. Campinas: Instituto Agronômico, 1983.31p.

RIEDELL, W.E.; KHOO, U.; INGLETT, G.E. Effects of bioregulators on soybean leaf structure and chlorophyll retention. In: PLANT GROWTH REGULATION, Lake Alfred, Florida, 1985. Proceedings. Lake Alfred, 1985. p. 204-212.

SAIMBHI, M.S.; ARORA, S.K.; CHHIBBA, I.M. Influence of seed treatment with 2-chloroethylphosphonic acid, gibberellic acid, ascorbic acid, and simazine on growth and nutrient composition of pea (Pisum sativum L.) seedlings. Plant and Soil, v.43, p.697-699, 1975.

SHARMA, K.; WALIA, N. Growth and yield of soybean Glycine max (L.) Merril as influenced by light and cytokinin. Environmental Ecology, v.14, p.307-310, 1996.

TANIMOTO, E. Gibberelin requirement for the normal growth of roots. In: TAKAHASHI, N.; PHINNEY, B. O.; MacMILlAN, J. (Ed.), Gibberelins. New York: Springer-Verlag, 1990. cap.22, p.229-240.

TENNANT, D.A. A test of a modified line intersect method of estimating root length. Journal of Ecology, v.63, p.995-1001, 1975.

URWILER, M.G.; STUTTE, C.A.; COOKE, A.R. Influence of $\mathrm{GA}_{3}$ on soybean reproductive growth. In: PLANT GROWTH REGULATION, Ithaca, 1988. Proceedings, Ithaca, 1988. p.67-68.

VALIO, I.F.M.; SCHWABE, W.W. Correlative growth in seedling of Phaseolus vulgaris L.: Inhibition of stem growth by the primary leaves. Annals of Botany, v.42, p.263-268, 1978.

YAMAGUCHI, S.; KAMIYA, Y. Gibberellin biosynthesis: Its regulation by endogenous and environmental signals. Plant and Cell Physiology, v. 41, p. $251-257,2000$.

Received March 25, 2002

Accepted October 15, 2002 